\title{
Thinking on Connection of Basic English Teaching and Vocational English Teaching in Higher Vocational Colleges
}

\author{
Fenghua Lai \\ Jiangxi Applied Engineering Vocational Institute, Pingxiang, Jiangxi, 337042, China
}

Keywords: higher vocational education; basic English teaching; vocational English teaching; teaching connection

\begin{abstract}
In English teaching activity of higher vocational colleges, basic English teaching and vocational English teaching are two different components. The organic combination of basic English teaching and vocational English teaching can overall improve students' comprehensive English quality, promote English knowledge application ability training and lay a solid foundation for their vocational development. In this paper, basic English teaching and vocational English teaching are organically combined to actively explore the effective connection measures so as to provide scientific guidance for English teaching reform in higher vocational colleges.
\end{abstract}

\section{Introduction}

The economic globalization develops deeply, and China overall drives the development strategy of "The Belt and Road". Under such social background, social demand for talents changes. The quality requirements for English talents improve obviously. Thus, higher vocational colleges should not just cultivate students' basic English knowledge, but also combine vocational development needs to explore the way to organically combine basic English teaching and vocational English teaching in talent training process. Meanwhile, higher vocational colleges should cultivate students' English knowledge mastery ability and vocational English quality, create conditions for students' future development and lay the foundation of technology-based applied talents for international development.

\section{Current Situation of English Teaching in Higher Vocational Colleges}

As education reform goes deep and talent training demand continues to change, higher vocational education receives extensive attention. Reform and innovation of higher vocational education become a key research problem in China's education field. In the report of the $19^{\text {th }}$ National Congress of the Communist Party of China, General Secretary Xi Jinping analyzed the development of vocational education, and considered that China should pay high attention to vocational education reform and facilitate vocational talent training in the new period. This has important influence for the development of higher vocational education in China. Through the proper study on English education and teaching organization in higher vocational colleges, we can find that, in traditional teaching organization activity, teachers only pay attention to explanation of basic English knowledge, and the link between English teaching and students' vocational development is not close enough. And, corresponding support cannot be provided for students' future vocational development. To be specific, at present, the problems of English teaching in higher vocational colleges are mainly embodied in the following aspects:

\subsection{English teaching objective of higher vocational colleges is mismatched with social demand}

Some teachers of higher vocational colleges pay excessive attention to basic English teaching and ignore the importance of vocational English. In the process of talent training, they fail to combine talent demand changes to adjust English teaching activity. As a result, English teaching lacks the link 
between social demand and students' vocational development. The characteristics of higher vocational education cannot be highlighted in English teaching practice. The students are difficult to apply English knowledge in vocational development after they enter the society. Talent training effect is not ideal enough. The role of English education and teaching is greatly restricted.

\subsection{English teaching content is disconnected with practical job demands}

As the development strategy of “The Belt and Road” goes deep and English talent training demand changes, some higher vocational colleges still use traditional teaching concept in talent training and fail to combine students' practical job demands to adjust English teaching activity. Besides, the ideological concept of vocational English teaching is insufficient. The teaching content can only serve for basic English education and cannot promote cultivation of vocational English capacity, which will hinder enhancement of students' comprehensive vocational skills and go against comprehensive improvement of vocational development level.

\subsection{The imbalanced English faculty structure}

Through the study on English education of higher vocational colleges, it is found that, the restriction of faculty will also have adverse effects on scientific development of English teaching activity. The systematic research shows that, English teacher is the dominator of English teaching activity in higher vocational colleges, and the quality of teachers will generate great influence on the teaching quality. But, English teachers in higher vocational colleges usually graduate from professional normal school, own good professional ability and English teaching theory and can deeply and systematically carry out English teaching and research activity. But these teachers lack practical experience and do not understand students' vocational development enough. Besides, their vocational English knowledge is insufficient. Thus, it is difficult for them to implement vocational English teaching activity. These will seriously hinder the advancement of teaching organization activity and go against cultivation of students’ vocational English ability.

\subsection{The single English evaluation method of higher vocational colleges}

In English teaching activity of higher vocational colleges, evaluation has the guiding function and will also influence English teaching and students' learning of English knowledge. The analysis on English examination of higher vocational colleges in China shows that, traditional test paper examination method is still applied, and student evaluation mainly refers to the examination result. The traditional examination method can neither make a correct judgement of students' English knowledge application ability and vocational English mastery nor implement corresponding guidance with the help of effective assessment. As a result, students are difficult to position their learning effect, and have low learning interest. In addition, the cultivation of students' practical ability for English knowledge will be seriously restricted. Finally, the teaching effect will be affected. Therefore in the new period, it is required to explore the reform measures from the perspective of examination and evaluation in English teaching reform process, and offer support for vocational English ability training.

\section{Ways to Effectively Connect Basic English Teaching and Vocational English Teaching in Higher Vocational Colleges}

In English teaching reform of higher vocational colleges, teachers should combine talent demand and students' vocational development demand to actively explore teaching reform measures, promote the effective connection between basic English teaching and vocational English teaching, facilitate vocational English ability training and provide support for students' development. During connecting basic English teaching and vocational English teaching, the exploration of connection ways can start from the following aspects: 


\subsection{Change teaching concept and deepen the cognition of teachers and students for English teaching}

During reform and innovation of English teaching activity in higher vocational colleges, the concept change of teachers and students generate the important influence on the connection effect of basic English and vocational English. So, in the process of teaching organization planning, English teachers in higher vocational colleges should actively change traditional teaching concept, correctly cognize the importance of vocational English, explore teaching reform measures based on the connection between basic English and vocational English, consciously impart vocational English knowledge to students, cultivate students' vocational English application ability and effectively promote enhancement of talent training effect. In the teaching activity, teachers should guide students, let them objectively treat the importance of vocational English teaching from the perspective of personal vocational development, and make them actively explore vocational English knowledge under the precondition of learning basic English knowledge and improve English learning interest and method. In the specific teaching practice, students' English application ability should be cultivated. Meanwhile, the link between English teaching and students' vocational development should be highlighted to make sure students can gain ideal learning effect on the basis of learning and exploration.

For computer majors, English teachers can consciously guide students to learn hardware basis, computer system maintenance, computer network basis, computer networking technology and IT vocational English in English teaching activity, and form all-round and systematic cognition of English knowledge in active matrix, application software, arithmetic operations, analog signals, ACPI (Advanced Configuration and Power Interface) and API (Application Programming Interface) so as to enhance their vocational English knowledge application ability and create conditions for better engaging in computer work.

\subsection{Update teaching content and choose suitable teaching method}

During exploring the connection between basic English teaching and vocational English teaching in higher vocational colleges, teachers should place the key point of teaching connection in the aspect of teaching content and teaching method improvement, make sure the teaching content and teaching method can embody the features of combination of learning with working, and assist students in exploring in the process of learning English knowledge. Under the condition of enhancing basic English learning effect, the English teaching mode which can highlight students' vocational development characteristics should be constructed to create the real language environment for students so that students can gradually improve vocational English learning ability. Besides, corresponding support and guarantee can be provided for students' future development ${ }^{[3]}$. In daily teaching organization activity, teachers may enhance students' listening, speaking, reading and writing abilities in basic English teaching, highlight cultivation of students' cross-cultural communication competence in vocational English teaching, really construct student-centered teaching mode, overall improve teaching effect of vocational English and make sure students can gain vocational English advantage and better development in future vocational development.

For example, in English teaching for tourism-related students in higher vocational college, teachers should not just enhance students' basic English and make theme grasp basic English words, listening, speaking, reading and writing skills, but also reform teaching contents in combination of students' vocational development demand, and introduce the teaching content about students' vocation, such as professional English knowledge about scenic spots like Immortality-pill-making Lake and Remnant Snow on the Broken Bridge; English knowledge about folk culture and legend like Chinese Cleopatra and Chinese Robin Hood; English knowledge about culinary culture like Chicken Cubes with Chili Pepper and Peanuts, Pork Chops with Sweet and Sour Flavor, Steamed Sliced Mutton with Beijing Scallion and Crisp Shrimps with Rice Wine Sauce. To highlight teaching effect, in the teaching activity, teachers may choose situation creation method to carry out scientific and effective teaching guidance, make students form profound cognition of English knowledge in the 
specific vocational situation and make sure students' comprehensive English learning effect is enhanced.

\subsection{Enhance teaching team building and improve teachers' vocational English teaching ability}

Based on the demand for basic English teaching and vocational English teaching, it is also required to pay attention to exploring the measures to cultivate excellent teachers, effectively improve English teachers' vocational English education ability and provide high-quality vocational English teaching guidance for students in order to improve the practical effect of English teaching activity $^{[4]}$. During exploring the measures for English teaching cultivation, multiple channels of advanced study opportunities may be provided for teachers. On the one hand, grassroots workers of relevant industries may be invited to offer guidance for English teachers so that they can form systematic cognition of vocational English and enhance application of vocational English knowledge in teaching activity. On the other hand, teachers may participate in advanced studies, deeply contact vocational English knowledge, enhance their ability to carry out vocational English teaching and promote overall enhancement of English teaching effect.

\subsection{Reform teaching evaluation and construct diversified evaluation modes}

Since traditional English examination and evaluation cannot provide effective support for basic English and vocational English teaching connection, and even will affect students' enthusiasm for vocational English learning, teachers may reform teaching evaluation during exploring English teaching reform. Based on sticking to traditional evaluation method, teachers may properly set practice-based evaluation items, namely, examine students' vocational English ability and judge students' vocational English application ability, so as to make sure teaching evaluation guidance function is further manifested.

\section{Summary}

In conclusion, teachers should study the demands of English teaching from multiple perspectives and formulate corresponding teaching organization scheme during reform and innovation of talent training based on the talent training objective of higher vocational colleges. Meanwhile, vocational English ability and basic English ability should be strengthened. Students' vocational competitiveness may be intensified to let them better devote themselves in the work practice and improve future development. In the new period, the realistic demands may be combined to construct the integrated teaching mode of vocational English and basic English, train international vocational technical talents and promote exertion of talent security effect in the process of reform and innovation of talent training in higher vocational colleges.

\section{References}

[1] Guan Xin, Reflection on Strengthening the Connection of Common English Teaching and Professional English Teaching, Journal of Tianjin Vocational Institutes, 2014, 15(11):56-59.

[2] Ma Shujun, Reflection on Effective Connection of Basic English and Professional English in Higher Vocational English Teaching, Wen Li Dao Hang, 2015(30):22-22.

[3] Zhu Xiaowei, Analysis on Connection of Basic English Teaching and Professional English Teaching in Higher Vocational Colleges, Journal of Taiyuan Urban Vocational College, 2015(7):133-134.

[4] Zheng Haiyan, Study on Connection between Basic English Teaching and Professional English Teaching in Higher Vocational Colleges, Qiu Zhi Dao Kan, 2017(13):129-129.

[5] Fan Junying, Connection Carrier Function of PRETCO in Basic English Teaching and Professional English Teaching in Higher Vocational Colleges, Overseas English, 2016(2):29-31. 